\title{
Strategi Peningkatan Daya Saing Kerajinan Bordir Melalui Pendekatan Analytical Hierarchy Process
}

\author{
Apip Supriadi ${ }^{1)}$ * \\ Gusti Tia Ardiani ${ }^{1)}$ \\ Andi Rustandi ${ }^{1)}$ \\ 1) Universitas Siliwangi
}

\begin{abstract}
ABSTRAK
Tujuan penelitian ini adalah i) melakukan analisis tentang daya saing kerajinan bordir Kota Tasikmalaya dan ii) merumuskan strategi peningkatan daya saing kerajinan bordir di Kota Tasikmalaya. Sedangkan target temuan pada penelitian ini adalah menemukan formulasi strategi dalam upaya meningkatkan daya saing kerajinan bordir Kota Tasikmalaya. Pendekatan untuk penyusunan strategi daya saing kerajinan bordir Kota Tasikmalaya adalah analisis multi kriteria (MCA = Multi Criteria Analysis) dengan metode analytical hierarchy process (AHP), dengan menggunakan software expertchoice for windows, di mana persepsi stakeholders menjadi pegangan dalam mengambil keputusan dan prioritas dalam penyusunan strategi daya saing kerajinan bordir. Hasil dari penelitian ini menunjukkan bahwa strategi peningkatan daya saing kerajinan bordir di Kota Tasikmalaya adalah strategi optimis.
\end{abstract}

Kata kunci: Daya Saing, Kerajinan Bordir, Proses Hirarki Analitik Klasifikasi JEL:

\section{Strategy to Improve the Competitiveness of Embroidery Craft Through Analytical Hierarchy Process Approach}

\begin{abstract}
The purpose of this research is i) to analyze the competitiveness of Tasikmalaya City embroidery and ii) to formulate a strategy to increase the competitiveness of embroidery craft in Tasikmalaya City. While the target findings in this study is to find a strategy formulation in an effort to improve the competitiveness of embroidery craft Tasikmalaya City. Approach for the preparation of competitiveness strategy of Tasikmalaya City embroidery craft is multi criteria analysis (MCA = Multi Criteria Analysis) with analytical hierarchy process (AHP) method, using expertchoice for windows software, where stakeholders' perceptions become the handles in decision making and priority in the preparation Strategy of competitiveness of embroidery craft. The results of this study indicate that the strategy to increase the competitiveness of bordir craft in Tasikmalaya City is an optimistic strategy.
\end{abstract}

Keywords: Competitiveness, Embroidery Craft, Analytical Hierarchy Process

\section{JEL classification:}

\section{PENDAHULUAN}

Kota Tasikmalaya merupakan salah satu kota di Jawa Barat yang terkenal dengan hasil kerajinannya. Kerajinan dari Kota Tasikmalaya yang terkenal antara lain: kerajinan bordir, anyaman mendong, anyaman bambu, alas kaki/ kelom geulis, kayu olahan, batik, payung geulis, dan makanan olahan.

Sentra industri bordir di Kota Tasikmalaya hingga kini terus berkembang. Pada tahun 2016, terdapat 1.397 unit, Tahun 2017 sebesar 1.401 unit dan Tahun 2018 sebesar 1.407 unit. Sentra industri kerajinan bordir yang terbesar adalah terdapat di Kecamatan Kawalu. Daerah yang dikenal sebagai sentra industri bordir di Kecamatan Kawalu yaitu Desa Tanjung, Kersamenak, Cibeuti, Cilamajang, Talagasari, Gunung Tandala, Karang Anyar, Gunung Gede, Leuwiliang dan Urug.

Dalam mendukung industri kerajinan bordir, Pemerintah Kota Tasikmalaya melalui Dinas Koperasi dan UMKM memberikan bantuan kepada para pengusaha kerajinan bordir untuk dapat mempromosikan sekaligus menjual produknya. Bantuan tersebut berupa fasilitas lokasi di Pasar 
Tabel 1. Data Potensi Industri Kota Tasikmalaya Tahun 2016 - 2018

\begin{tabular}{|c|c|c|c|c|}
\hline $\mathrm{No}$ & Komoditi Unggulan & \multicolumn{3}{|c|}{ Unit Usaha } \\
\hline 1 & Bordir & 1.397 & $\frac{2017}{1.401}$ & $\frac{2010}{1.407}$ \\
\hline 2 & Kerajinan Anyaman Mendong & 174 & 174 & 174 \\
\hline $\begin{array}{l}3 \\
4 \\
5 \\
6 \\
7 \\
8\end{array}$ & $\begin{array}{l}\text { Kerajinan Anyaman Bambu } \\
\text { Alas Kaki (kelom dan sandal) } \\
\text { Kayu Olahan } \\
\text { Batik } \\
\text { Payung Geulis } \\
\text { Makanan Olahan }\end{array}$ & $\begin{array}{r}75 \\
523 \\
211 \\
41 \\
8 \\
552 \\
2.981\end{array}$ & $\begin{array}{r}75 \\
525 \\
213 \\
41 \\
8 \\
560 \\
2997\end{array}$ & $\begin{array}{r}75 \\
536 \\
217 \\
41 \\
8 \\
656 \\
3.114\end{array}$ \\
\hline
\end{tabular}

Sumber: Dinas Koperasi, Usaha Mikro Kecil dan Menengah, Perindustrian dan Perdagangan Kota Tasikmalaya

Tanah Abang sebagai pusat penjualan bordir asal Tasikmalaya tepatnya di blok F2 lantai 5. Selain itu pula, pemasaran tidak terbatas hanya di Pasar Tanah Abang tetapi juga ke Pasar Tegal Gubug Cirebon, Pasar Turi Surabaya, Pasar Klewer Solo, Pulau Batam, Makasar, Pontianak danlain-lain.

Selain pasar nasional, Bordir Tasikmalaya juga telah menembus pasar internasional, diantaranya telah di ekspor ke Malaysia, Brunei Darussalam, Saudi Arabia, Singapura dan Afrika. Bentuk bantuan lainnya yang diberikan Pemerintah Kota Tasikmalaya kepada para pengrajin yaitu pelatihan pengoperasian penggunaan mesin bordir komputer kepada para pengusaha kecil khususnya bagi mereka yang belum memiliki mesin bordir komputer.

Meskipun jumlah unit usaha kerajinan bordir terus meningkat dan juga adanya bantuan yang diberikan Pemerintah Kota Tasikmalaya kepada pengusaha kerajinan bordir, pada kenyataannya masih terdapat beberapa usaha yang belum berhasil dalam kegiatan usahanya dikarenakan tidak mampu bersaing dengan pengusaha bordir yang lain khususnya mereka yang memiliki finansial yang kuat sehingga menghentikan kegiatan usahanya (mengalami gulung tikar). Kemudian perkembangan kerajinan Kota Tasikmalaya yang terbawa dengan produk massal dengan meninggalkan produk eksklusif. Pengrajin bordir misalnya telah meninggalkan bordir manual dan beralih pada bordir dengan sistem komputerisasi yang notabene kalah bersaing dengan bordir komputer dari wilayah lain.

Selain itu, adanya produk kerajinan bordir buatan china di pasaran juga sedikit banyak menjadi ancaman bagi para pengusaha bordir Kota Tasikmalaya. Bordir China tersebut dirasakan sebagai ancaman karena mereka berani menjual produk kerajinan tersebut dengan harga yang lebih murah dibandingkan dengan harga kerajinan bordir produk Kota Tasikmalaya, sehingga hal tersebut berakibat terjadinya penurunan omset pada para pengusaha.

\section{Bordir}

Seni hiasan bordir pertama kali muncul di Byzantium tahun 330 masehi. Definisi bordir menurut Kamus Besar Bahasa Indonesia adalah hiasan rajutan benang pada kain. Terdapat beberapa alat yang digunakan untuk membuat hiasan bordir, selain benang dan jarum, alat lain yang digunakan adalah mesin jahit dan pemidangan kemudian dikenal dengan adanya mesin juki. Seiring perkembangan teknologi, sekarang terdapat mesin bordir yang menggunakan teknologi komputer.

Industri kerajinan bordir di Kota Tasikmalaya sudah dikenal dan dirintis sejak tahun 1925 dan telah berperan mendorong peningkatan pendapatan masyarakat, disamping pekerjaannya sebagai petani. Seni bordir datang ke Tasikmalaya sebagai serapan dari kebudayaan China. Perintis kerajinan bordir Tasikmalaya adalah Ibu Umayah dari desa Tanjung Kawalu. Sebelumnya Ibu Umayah yang pada tahun sebelumnya bekerja di perusahaan Amerika Singer. Setelah menguasai bidang bordiran saat di Singer, ia keluar daan kembali ke Desa Tanjung dan membuka usaha kecil-kecilan dengan menerima pesanan bordir baik dari Tasikmalaya maupun dari luar daerah. Dalam waktu 50 tahun, industri kerajinan bordir semakin berkembang. Awalnya kerajinan bordir ini hanya untuk memenuhi kebutuhan pakaian wanita, kemudian berkembang memproduksi kerudung, kebaya, mukena, tunik, selendang, blus, rok, sprei, sarung bantal, taplak meja, baju gamis, baju koko, kopiah haji, hingga busana sehari-hari yang dihiasi dengan bordir menarik.

\section{Competitive Strategy}

Competitive strategy yang tepat harus 
Gambar 1. Model Konseptual Dikembangkan dari Model Diamod Porter, (1990) dan Kotler, (1997)

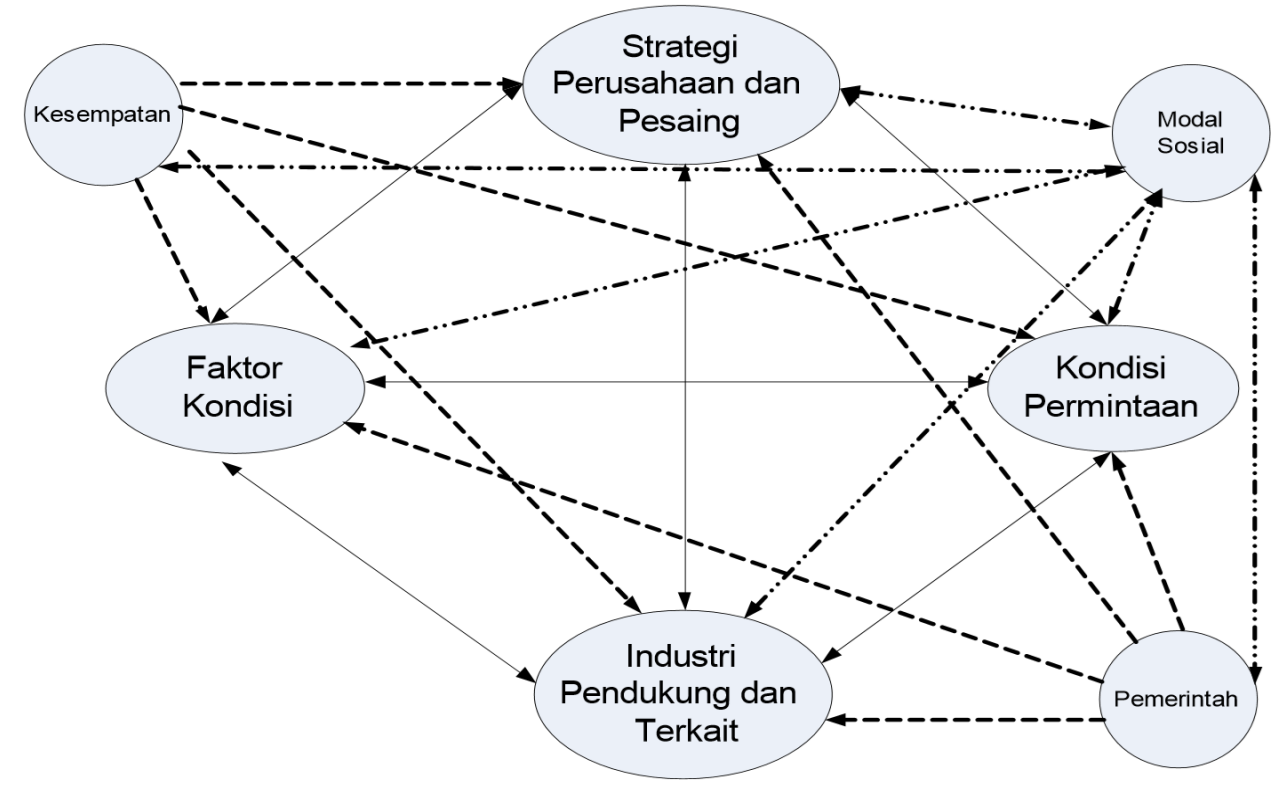

digunakan dalam memenangkan persaingan tersebut, Porter (1980) mengemukakan ada 3 Generic Strategy yang bisa digunakan dalam memenangkan Persaingan tersebut, yaitu:

a. Cost Leadership: yaitu keunggulan dalam biaya yang tercermin dari skala produksi, sehingga menciptakan efisiensi dan penurunan biaya per unit .

b. Differentiation: dengan menciptakan produk yang unik atau berbeda dengan saingan, keunikan tersebut bisa tercipta dari disain, tampilan, packeging atau fungsi dari produk melebihi produk saingan.

c. Focus Strategy yaitu dengan mengkhususkan pelayanan terhadap pangsa pasar tertentu yang dinilai layak atau memanfaatkan ceruk pasar/ market niche yang ada sehingga berhasil mendapatkan keuntungan tanpa harus berhadapan dengan pemimpin pasar.

Model acuan lain yang dapat digunakan untuk mengkaji daya saing adalah model diamond (Porter, 1990), yaitu faktor kondisi, kondisi permintaan, industri pendukung dan terkait, strategi perusahaan dan persaingan, peran pemerintah, dan kesempatan dengan menambahkan variabel modal sosial (Kotler 1997). Selanjutnya dari dimensidimensi tersebut digunakan untuk mengukur daya saing klaster industri. Berdasarkan dimensidimensi utama pada model konseptual tersebut dikembangkan menjadi model operasional. Dimensi faktor kondisi dibangun oleh elemen sumber daya manusia, sumber daya alam (raw material), dan pemodalan. Dimensi kondisi permintaan dibangun oleh elemen sumber permintaan, jumlah permintaan, pemasaran produk, kualitas produk, desain produk, dan variasi produk. Dimensi industri pendukung dan terkait dibangun oleh elemen letak geografis, proses pengadaan, kualitas bahan pendukung, pelatihan pemakaian bahan pendukung. Dimensi strategi perusahaan dan persaingan dibangun oleh elemen produk baru, penurunan harga produk dan biaya produksi, dan teknologi baru. Dimensi peran pemerintah dibangun oleh elemen program fasilitasi, pelatihan, dan kebijakan. Dimensi kesempatan dibangun oleh elemen alat teknologi dan kondisi politik. Dimensi modal sosial dibangun oleh elemen komunikasi dan interaksi, kekeluargaan, kejujuran, kerja sama, dan peraturan. Sedangkan ukuran daya saing yang digunakan adalah nilai ekspor dan volume ekspor. Lebih jelasanya lihat gambar 1.

Y. Sri Susilo, (2010). Meneliti tentang Strategi Meningkatkan Daya Saing UMKM Dalam Menghadapi Implementasi CAFTA Dan MEA. Dalam penelitiannya diperoleh informasi bahwa agar tetap mampu bertahan dan memanfaatkan peluang dari pelaksanaan CAFTA dan MEA, maka usaha kecil harus meningkatkan daya saing bisnis mereka dan daya saing produk mereka. Pengusaha/ pemilik usaha kecil dengan semangat kewirausahaan dan inovasi, harus menjadi kekuatan pendorong untuk meningkatkan daya saing bisnis mereka. Dengan meningkatkan daya saing bisnis maka pada gilirannya akan mendorong terciptanya 
daya saing produk. Hal lain yang harus menjadi prioritas dari usaha kecil yang meningkatkan kerjasama antara unit-unit usaha kecil atau antara pusat-pusat usaha kecil dan juga meningkatkan jaringan kerjasama dengan pemangku kepentingan. Selain itu peran pemerintah diharapkan sebagai pelengkap untuk mendorong berbagai upaya yang dilakukan oleh usaha kecil untuk meningkatkan daya saing mereka. Dengan iklim usaha yang kondusif yang diciptakan oleh pemerintah, itu akan memfasilitasi usaha kecil untuk meningkatkan daya saing mereka. pemangku kepentingan lainnya harus meningkatkan kemitraan yang diciptakan oleh usaha kecil, baik dalam bentuk pendidikan dan pelatihan, promosi, dan fasilitas pendukung lainnya.

Abror, (2011). Meneliti tentang Strategi Bersaing Pengusaha Kecil Sulaman/Bordir Di Kota Padang. Hasil penelitian menunjukkan bahwa, pengusaha sulaman bordir di Kota Padang lebih memilih strategi keunggulan biaya sebagai strategi bersaing dibandingkan dengan strategi focus. Pengelompokan strategi bersaing yang dipilih tidak dipengaruhi secara signifikan oleh variabel jumlah penjualan, umur usaha serta jumlah kekayaan bersih. Berdasarkan kondisi yang ada strategi yang lebih tepat untuk dipilih adalah strategi focus, karena tidak membutuhkan modal besar namun membutuhkan inovasi agar bisa mencari ceruk pasar dan masuk ke segmen tertentu saja. Pengusaha sulaman bordir di kota Padang belum mampu mengkombinasikan antara sumberdaya yang dimiliki dengan strategi bersaing yang dipilih agar mampu menciptakan keunggulan bersaing yang berkelanjutan.

Naniek Utami Handayani dkk, (2012). Meneliti tentang Faktor-Faktor Yang Memengaruhi Peningkatan Daya Saing Klaster Meubel Di Kabupaten Jepara. Hasil penelitian menunjukkan bahwa faktor-faktor yang memengaruhi daya saing di klaster Mulyoharjo adalah faktor kondisi, kondisi permintaan, industri pendukung dan terkait, serta strategi perusahaan. Sedangkan untuk klaster Senenan adalah faktor kondisi, peran pemerintah, kesempatan dan modal sosial.

Stevia Septiani dkk, (2013). Meneliti tentang Pengaruh Entrepreneurial Marketing Dan Kebijakan Pemerintah Terhadap Daya Saing Industri Alas Kaki Di Bogor. Hasil penelitian, diketahui bahwa karakteristik pelaku industri kecil alas kaki di Bogor termasuk pada kelompok berpendidikan rendah, namun memiliki keahlian sangat baik dalam memproduksi alas kaki. Karakteristik usaha alas kaki di Bogor termasuk pada usaha yang telah lama berdiri dengan kategori IK dan merupakan usaha atau bisnis utama keluarga. Selanjutnya, diketahui bahwa peubah laten entrepreneurial marketing berpengaruh secara positif dan langsung terhadap daya saing industri kecil alas kaki di Bogor. Sedangkan peubah laten kebijakan pemerintah ternyata memiliki dampak langsung dan positif terhadap entrepreneurial marketing, sehingga dapat diartikan bahwa terdapat pengaruh tidak langsung antara kebijakan pemerintah terhadap daya saing melalui entrepreneurial marketing.

Lila Bismala, (2014). Meneliti tentang Analisis Strategi Pemasaran Pada UMKM Di Sumatera Utara Untuk Meningkatkan Daya Saing UMKM. Hasil penelitian menunjukkan bahwa secara umum UMKM belum mengaplikasikan manajemen pemasaran, namun hanya berdasarkan pemahaman dan pengetahuan yang dimiliki saja. Berdasarkan analisis SWOT yang dilakukan, diperoleh strategi manajemen pemasaran yang dapat diimplementasikan, yaitu Strategi S-O, meliputi memberikan inovasi produk yang memperkuat posisi, membentuk citra merk sendiri tanpa mendompleng merk lain. Strategi W-O, meliputi memperkenalkan keluar daerah dengan teknologi informasi, memperpanjang daur hidup produk dengan melakukan diferensiasi, mencari sistem pemasaran selain sistem konsinyasi. Strategi S-T, yaitu memperkuat/ menonjolkan ciri khas kedaerahan. Strategi W-T, membuat kemasan yang inovatif dengan merk khas, memperkenalkan wilayah usaha dengan kluster produk.

Yuliarma, (2014). Meneliti tentang Peningkatan Kreativitas Dan Aktivitas Industri Bordir Minangkabau Melalui Model Pembelajaran Desain Di Balai Diklat Indusri (BDI) Regional II Padang. Hasil penelitian, Dengan memberikan pengalaman belajar kepada peserta diklat desain bordir di BDI regional II Padang melalui penerapan model pembelajaran desain dengan metode training model, yaitu metode latihan berulang-ulang menciptakan desain inovatif sesuai kebutuhan industri dan harapan konsumen, maka keterampilan kreativitas SDM meningkat. Dengan melakukan latihan berkali-kali dan terus menerus secara teratur pengetahuan dan ketrampilan tersebut dapat dikuasai dengan baik dan sempurna. Pada 
Tabel 2

Kriteria Penilaian Pemilihan Strategi Daya Saing Kerajinan Bordir di Kota Tasikmalaya

\begin{tabular}{|c|c|c|}
\hline No & Kriteria & Sub Kriteria \\
\hline & & Sumber Daya Manusia \\
\hline \multirow[t]{4}{*}{1} & Faktor Kondisi & Sumber Daya Alam \\
\hline & & Modal \\
\hline & & Sumber Permintaan \\
\hline & & Jumlah Permintaan \\
\hline \multirow{5}{*}{2} & Kondici Pormintarn & Pemasaran Produk \\
\hline & Nomaist i emmintadan & Kualitas Produk \\
\hline & & Desian Produk \\
\hline & & Variasi \\
\hline & & Letak \\
\hline \multirow{4}{*}{3} & Ind11stri Pend11k11no & Proses Pengadaan \\
\hline & & Kualitas Bahan Pendukung \\
\hline & & Pelatihan Memakai Bahan \\
\hline & & Produk Baru \\
\hline \multirow[t]{3}{*}{4} & Strategi Perusahaan dan Pesaing & Penurunan Harga dan Biaya \\
\hline & & Teknologi Baru \\
\hline & & Kebijakan \\
\hline \multirow[t]{2}{*}{5} & Peran Pemerintah & Pelatihan \\
\hline & & Program Fasilitas \\
\hline \multirow{2}{*}{6} & Vonomnoton & Alat Teknologi \\
\hline & Kesempatan & Kondisi Politik \\
\hline \multirow{5}{*}{7} & & Komunikasi dan Interaksi \\
\hline & & Kekeluargaan \\
\hline & Modal Sosial & Kejujuran \\
\hline & & Kerjasama \\
\hline & & Aturan-aturan \\
\hline
\end{tabular}

gilirannya, jika keterampilan kreativitasnya dalam mendesain produk inovatif menigkat; tentunya produk bordir Minangkabau mampu bersaing kuat di pasar Internasional sehingga aktivitas industri meningkat dan produktivitas meningkat.

Jumie Sephy Rahayu dkk (2015). Meneliti tentang Perancangan Strategi Untuk Meningkatkan Kinerja Inovasi Pada Klaster Industri Kreatif Batik Laweyan. Hasil penelitian, (1) klaster industri kreatif Kampoeng Batik Laweyan berada pada kuadran I, yaitu posisi agresif dan ekspansi sehingga strategi yang digunakan adalah memanfaatkan kekuatan untuk mengoptimalkan peluang. Subkriteria yang paling berpengaruh dalam pemilihan strategi adalah subkriteria Price (P2) dan Profit rate (M4). Strategi yang menjadi prioritas akhir yaitu penguatan brand Kampoeng Batik Laweyan dan Pengembangan kampung wisata edukasi.

\section{DATA DAN METODOLOGI}

\section{Data Penelitian}

Data pada penelitian ini terdiri dari data sekunder dan data primer. Data sekunder diperoleh dari Dinas Indag UMKM dan Bappeda Kota Tasikmalaya sedangkan data primer diperoleh dengan menyebar kuesioner kepada responden (pengrajin dan Instansi terkait). Sampel pada penelitian ini sebanyak 100 responden pengrajin bordir dan 9 responden instansi terkait. Kuesioner yang terkumpul kemudian di rekap dan ditabulasi, dan hasil rekapan ini digunakan sebagai bahan dalam kegiatan Focus Group Discussion (FGD) sebelum diolah dengan menggunakan software expertchoice for windows

\section{Pendekatan Penelitian}

\section{Analisis Multi Kriteria}

Pendekatan yang digunakan untuk penyusunan strategi daya saing kerajinan bordir adalah dengan analisis multi kriteria $(\mathrm{MCA}=$ Multi Criteria Analysis) dengan menggunakan software expertchoice for windows, di mana persepsi stakeholders menjadi pegangan dalam mengambil keputusan dan prioritas dalam penanganan kerajinan bordir. Analisis Multi Kriteria (Multi 
Criteria Analysis) merupakan alternatif teknik yang mampu menggabungkan sejumlah kriteria dengan besaran yang berbeda (multi-variable) dan dalam persepsi pihak terkait yang bermacammacam (multi-facet).

\section{Penentuan Multi Kriteria}

Proses pengambilan keputusan dengan menggunakan multikriteria bisa dilakukan dengan menggunakan metode analytical hierarchy process (AHP). Dalam penggunaan metode AHP, perlu dilakukan dekomposisi masalah dengan mengidentifikasi kriteria dan subkriteria yang akan digunakan. Kriteria utama dalam pemilihan strategi daya saing kerajinan bordir adalah aspek faktor produksi, aspek kondisi permintaan, aspek industri pendukung, aspek strategi perusahaan dan pesaing, aspek peran pemerintah, aspek kesempatan dan aspek modal sosial. Aspek utama ini dibagi dalam subkriteria, tiga subkriteria faktor kondisi, enam subkriteria kondisi permintaan, empat subkriteria industri pendukung, tiga subkriteria strategi perusahaan dan pesaing, tiga subkriteria peran pemerintah, dua subkriteria kesempatan dan lima subkriteria modal social. Selengkapnya dapat dilihat pada tabel 2.

Multi kriteriaini membentuk proses hierarki analisis, dengan tujuan (goal) berada dikedudukan paling atas, dan diikuti dengan kriteria utama, subkriteria, dan alternatif permasalahan. Hierarki penelitian yang telah disusun merupakan dasar dalam penyusunan kuesioner dan pengolahan data. Subkriteria-subkriteria tersebut masingmasing diberi kode nama untuk mempersingkat dan memudahkan dalam pengolahan data. Adapun hierarki penelitian pada gambar 2 :

\section{Penyusunan Kuesioner}

Kuesionerdisusunberdasarkanmultikriteria yang telah di tetapkan (Tabel 2). Setiap kriteria dan sub kriteria yang setingkat dibandingkan untuk membentuk matriks perbandingan berpasangan. Nilai yang digunakan menunjukkan hubungan perbandingan antara satu elemen dengan elemen yang kedua (Tabel3).

\section{HASIL DAN PEMBAHASAN \\ Analisis Daya Saing Kerajinan Bordir Kota Tasikmalaya}

Untuk mengetahui kemampuan bersaing Usaha Kecil Menengah sektor Bordir dilakukan dengan menyebar kuesioner kepada para pengrajin dan dinas terkait guna memperoleh informasi yang peneliti perlukan. Kuesioner yang terkumpul dari responden kemudian di tabulasi, selanjutnya dilakukan analisis menggunakan expert choise melalui metode FGD dengan expert.

Berdasarkan hasil pengolahan data diperoleh informasi perbandingan berpasangan tingkat kepentingan antar kriteria seperti tampak pada gambar 3 :

Berdasarkan gambar di atas, bahwa kriteria untuk meningkatkan daya saing kerajinan bordir paling penting secara berurutan adalah strategi perusahaan dan daya saing $(0,257)$, kesempatan $(0,238)$, kondisi permintaan $(0,195)$, faktor kondisi $(0,158)$, modal social $(0,107)$, industri pendukung $(0,026)$ dan peran pemerintah $(0,018)$.

Adapun hasil pengolahan AHP menggunakan expert choise selengkapnya dapat dilihat pada gambar 4 .

\section{Gambar 2. Hierarki Penelitian}

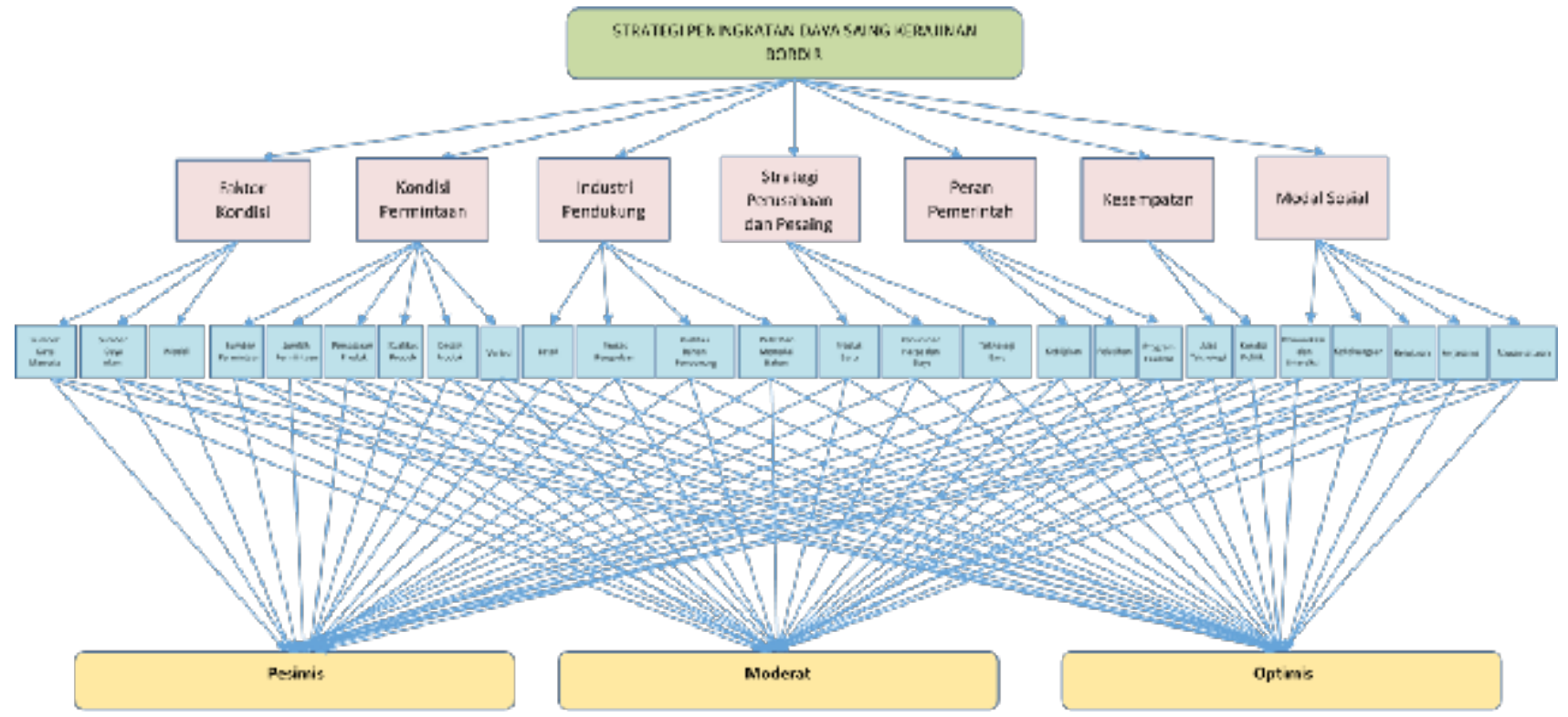


Tabel 3

Skala Banding Berpasangan

\begin{tabular}{|c|c|c|c|c|}
\hline Kepentingan & \multicolumn{4}{|c|}{ Definisi } \\
\hline 1 & \multicolumn{4}{|c|}{ Kedua elemen sama penting } \\
\hline 3 & \multicolumn{4}{|c|}{ Elemen yang satu agak lebih penting dibanding elemen yang kedu } \\
\hline 5 & \multicolumn{4}{|c|}{ Elemen yang satu lebih penting dibanding elemen yang kedua } \\
\hline 7 & \multicolumn{4}{|c|}{ Elemen yang satu sangat lebih penting dibanding elemen yang ke } \\
\hline 9 & \multicolumn{4}{|c|}{ Elemen yang satu mutlak lebih penting disbanding elemen yang $\mathrm{k}$} \\
\hline $2,4,6$ & \multicolumn{4}{|c|}{ Nilai-nilai antara diantara dua nilai yang berdekatan } \\
\hline \multirow[t]{3}{*}{ Kebalikan } & \multicolumn{4}{|c|}{$\begin{array}{l}\text { Jika aktivitas I mendapat suatu angka terhadap j, maka j mem } \\
\text { nilai kebalikannya bila dibandingkan dengan } \mathrm{i}\end{array}$} \\
\hline & \multicolumn{4}{|c|}{$\begin{array}{l}\text { Contoh Pengisian Kuesioner : } \\
\text { Pada level Kriteria, Sub Kriteria dan Alternatif }\end{array}$} \\
\hline & $\begin{array}{l}\text { Faktor } \\
\text { Kondisi }\end{array}$ & $\begin{array}{l}\text { Kondisi } \\
\text { Permintaan }\end{array}$ & $\begin{array}{c}\text { Industri } \\
\text { Pendukung }\end{array}$ & $\begin{array}{c}\text { Strategi } \\
\text { Perusahaan } \\
\text { dan Pesaing }\end{array}$ \\
\hline Faktor & & 2 & 7 & $1 / 3$ \\
\hline $\begin{array}{l}\text { Permisi } \\
\text { Permintaaan }\end{array}$ & & & 4 & $1 / 2$ \\
\hline Pendukung & & & & $1 / 4$ \\
\hline
\end{tabular}

Penjelasan :

Kolom 3 baris 1 : Faktor Kondisi 2 kali lebih penting daripada kondisi permintaan

Kolom 4 baris 1 : Faktor Kondisi 7 kali lebih penting dari industry pendukung

Kolom 5 baris 1 : Strategi Perusahaan dan Pesaing 3 kali lebih penting daripada Faktor Kondisi

Gambar 3. Perbandingan berpasangan tingkat kepentingan antar kriteria

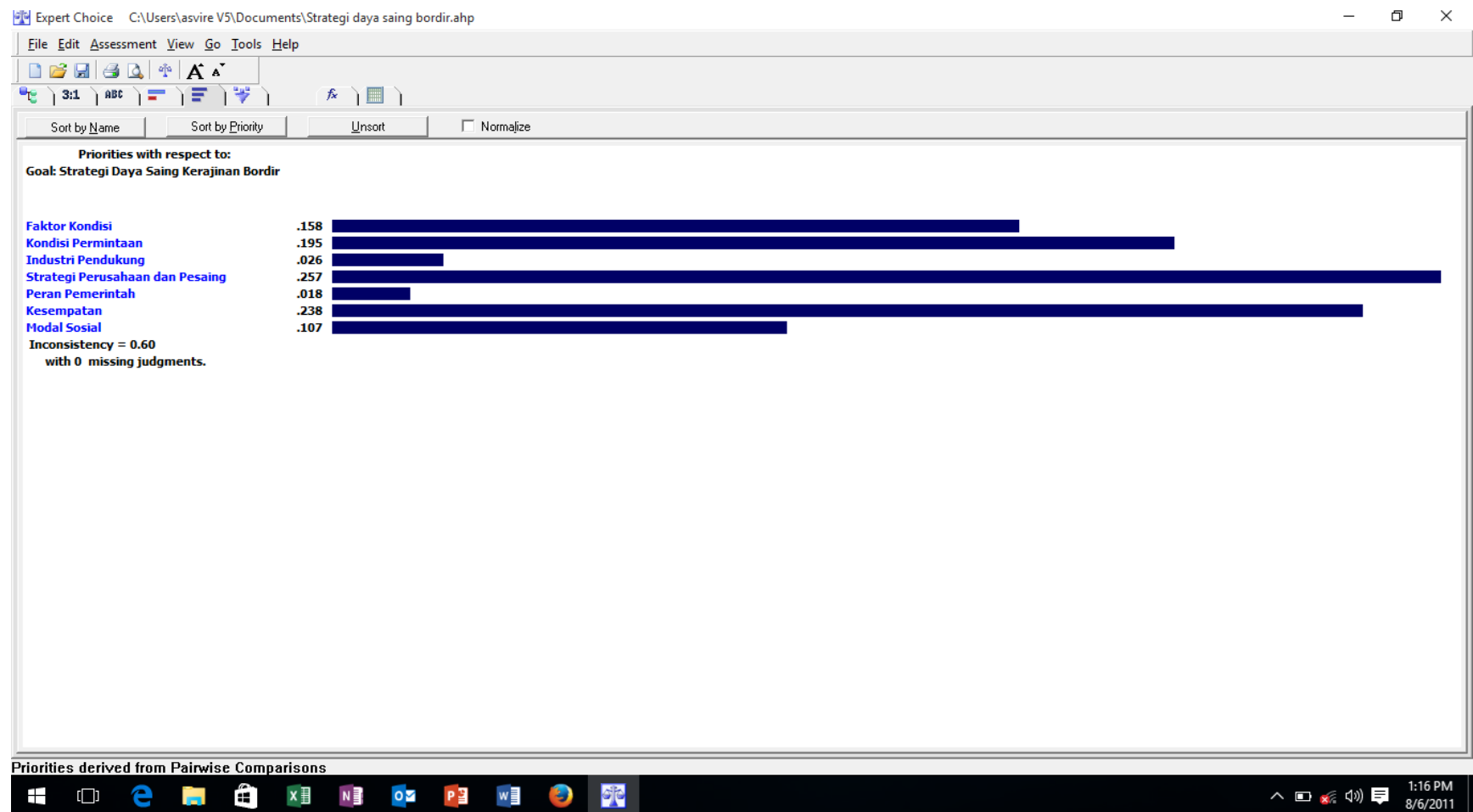


Gambar 4. Nilai Prioritas Alternatif Secara global

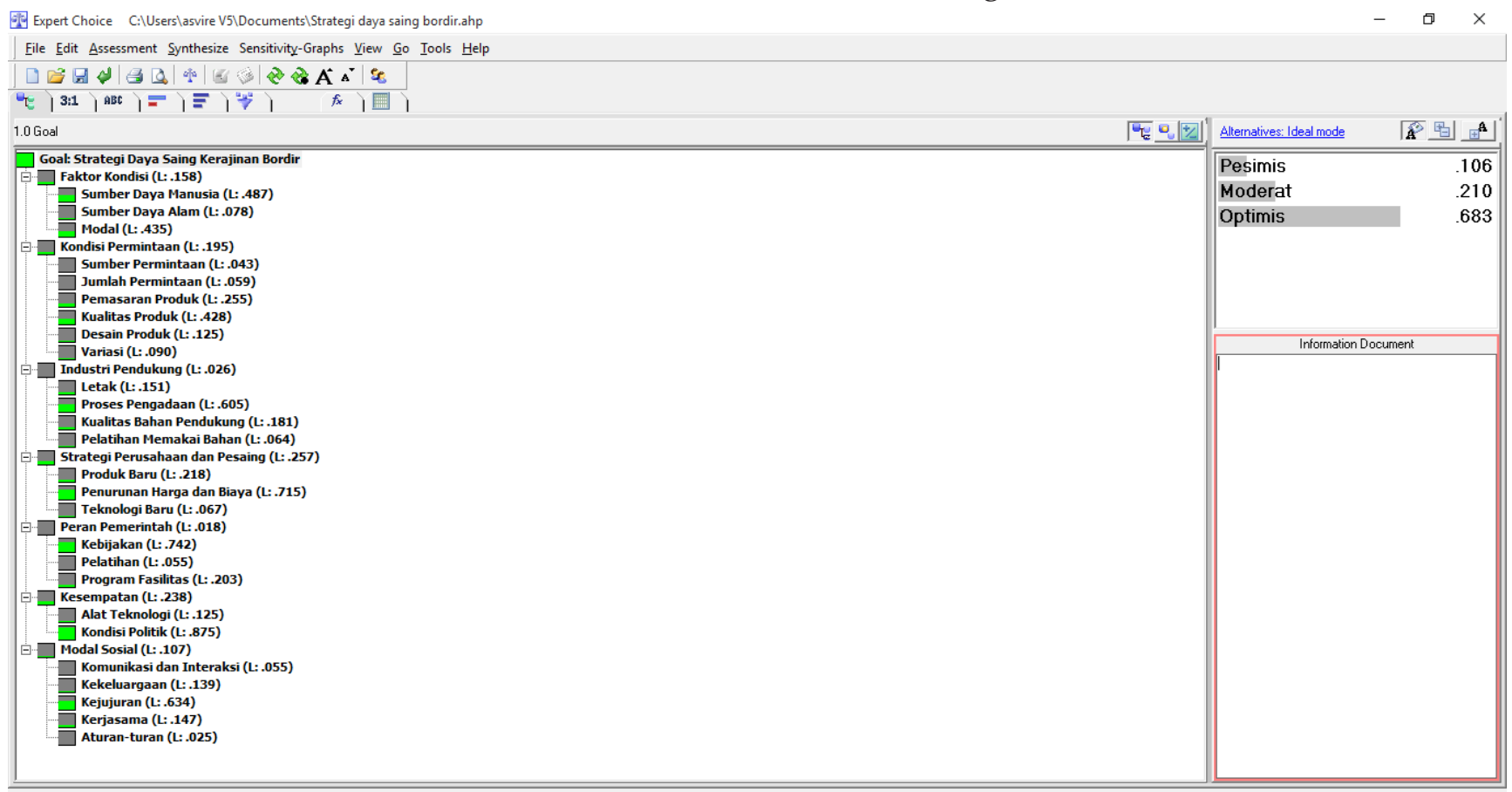

\#

Gambar 5. Perbandingan berpasangan tingkat kepentingan antar kriteria

Ff Facilitator: Head-to-Head Sensitivity for nodes below -- Goal: Strategi Daya Saing Kerajinan Bordir

File Options Head to headfrom Window

A $|\operatorname{ses}| \mathrm{x}|\mathrm{g}| \mathrm{E}|\mathrm{G}| \mathrm{X}$

Pesimis | Moderat |

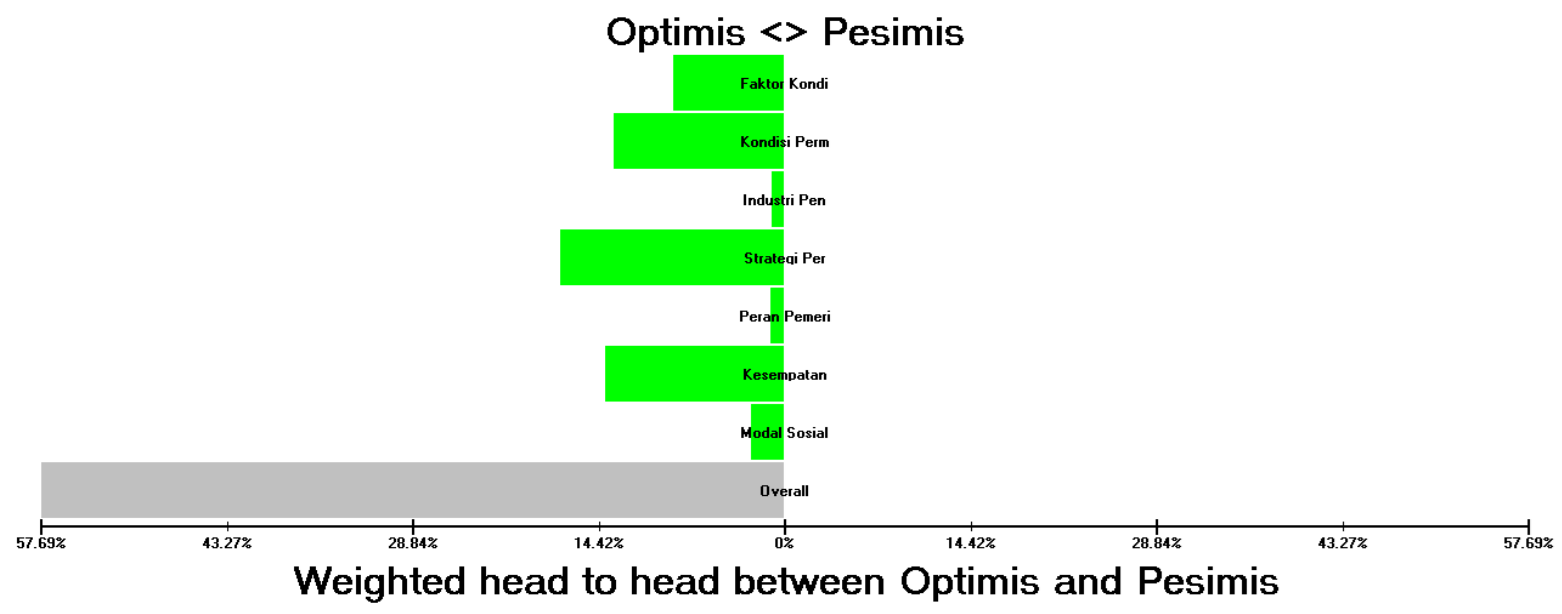

Sensitivity w..t: Goal: Strategi Daya Saing Keraininan Bordir

Sumber : Hasil olah data expert choice

Hasil perhitungan kemudian diurutkan dimulai dari nilai tertinggi sampai dengan nilai terendah. Berdasarkan nilai tersebut dapat diketahui kelebihan dan kekurangan alternatif strategi peningkatan daya saing kerajinan bordir di Kota Tasikmalaya
Rumusan Strategi Peningkatan Daya Saing Kerajinan Bordir Kota Tasikmalaya

Untuk menentukan rumusan strategi peningkatan kerajinan bordir terlebih dahulu dilakukan penentuan prioritas alternative seperti tampak pada gambar 5 . 


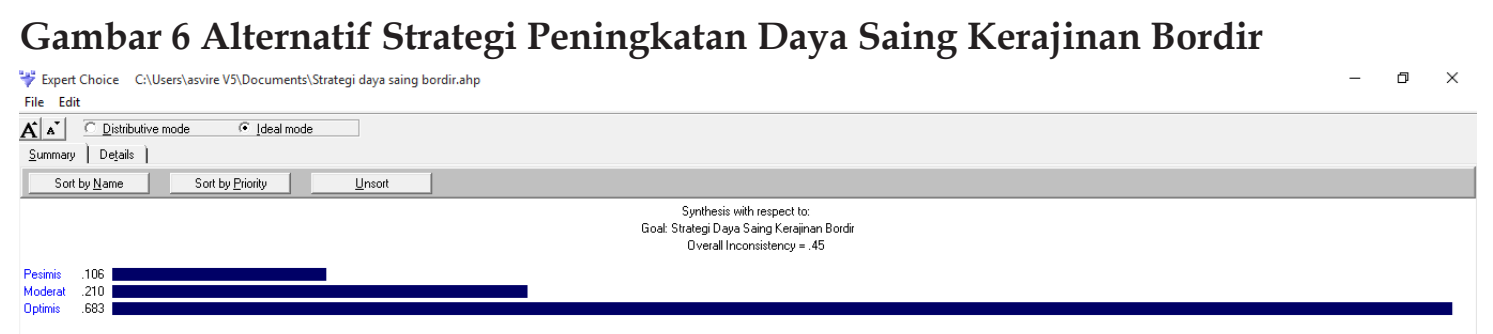

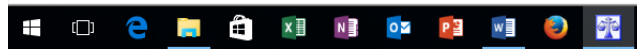

Berdasarkan pendapat responden dan expert, untuk masing-masing alternatif strategi, maka strategi peningkatan daya saing kerajinan bordir di Kota Tasikmalaya adalah strategi optimis, hal ini di sebabkan karena di dukung oleh ketersediaan sumber daya manusia, modal, sumber permintaan, jumlah permintaan, pemasaran produk, kualitas produk, desain produk, variasi, proses pengadaan, pelatihan memakai bahan, produk baru, penurunan harga dan biaya, teknologi baru, kebijakan, pelatihan, program fasilitas, alat teknologi, komunikasi dan interaksi, kekeluargaan dan kejujuran. Secara garifis ditunjukkan sebagai pada gambar 6 .

\section{SIMPULAN}

Dengan memperhatikan hasil pengolahan data dan kelebihan serta kekurangan alternatif strategi peningkatan daya saing kerajinan bordir di Kota Tasikmalaya, maka strategi optimis akan direkomendasikan untuk menjadi strategi peningkatan daya saing kerajinan bordir di Kota Tasikmalaya. Hal ini didukung oleh komponen ketersediaan sumber daya manusia, modal, sumber permintaan, jumlah permintaan, pemasaran produk, kualitas produk, desain produk, variasi, proses pengadaan, pelatihan memakai bahan, produk baru, penurunan harga dan biaya, teknologi baru, kebijakan, pelatihan, program fasilitas, alat teknologi, komunikasi dan interaksi, kekeluargaan dan kejujuran yang terdapat pada pengrajin kerajinan bordir.

\section{SARAN}

Dengan memperhatikan hasil pengolahan data, maka untuk meningkatkan daya saing kerajinan bordir di Kota Tasikmalaya, yang masih lemah adalah penentuan letak usaha dan kualitas bahan pendukung. Sementara komponen yang lainnya berdasarkan hasil olahan data menunjukkan kecenderungan mendukung untuk meningkatkan daya saing kerajinan bordir di Kota Tasikmalaya.

\section{REFERENSI}

Abror, 2011. Strategi Bersaing Pengusaha Kecil Sulaman/Bordir Di Kota Padang. Terdapat pada Http://Abrorfeunp.Blogspot.Co.Id/ 2011/01/Strategi-Bersaing-Pengusaha-

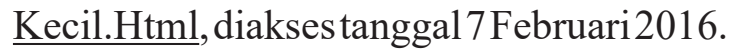

Bismala, L. 2014. Analisis Strategi Pemasaran Pada Umkm Di Sumatera Utara Untuk Meningkatkan Daya Saing UMKM. Jurnal Pembangunan Perkotaan Vol.2 No. 2

Badan Penelitian Dan Pengembangan Pemerintah Kota Medan Desember 2014

Handayan, N.U., Santoso, H., dan Pratama, A.I. 2012. Faktor-Faktor Yang Memengaruhi Peningkatan Daya Saing Klaster Mebel Di Kabupaten Jepara. Jurnal Teknik Industri, Vol. 13,No. 1, Februari2012:22-30

Kotler, P., Jatusripitak, S., and Maesincee, S. 1997. 
The Marketing of Nations, A strategic Approach to Building National Wealth, The Free Press, New York.

Porter, Michael, E. 1980. Competitive Strategy. New York, Free press

Porter, M. 1990. The Competitive Advantage of Nations, New York.

Porter, M.E. 1998. On Competition. Boston: Harvard Business School Publishing.

Rahayu, J.S., Syairudin, B. dan Pertiwi, S.G. 2015. Perancangan Strategi Untuk Meningkatkan Kinerja Inovasi Pada Klaster Industri Kreatif Batik Laweyan. Prosiding Seminar Nasional Manajemen Teknologi XXII Program Studi MMT-ITS, Surabaya 24 Januari 2015
Septiani, S., Sarma, M., dan Limbong, W.H. 2013. Pengaruh Entrepreneurial Marketing Dan Kebijakan Pemerintah Terhadap Daya Saing Industri Alas Kaki Di Bogor. Jurnal Manajemen Dan Organisasi Vol IV, No 2, Agustus 2013

Susilo, Y.S. 2010. Strategi Meningkatkan Daya Saing Umkm Dalam Menghadapi Implementasi CAFTA Dan MEA. Buletin Ekonomi Vol. 8, No. 2, Agustus 2010 Hal 70-170

Yuliarma. 2014. Peningkatan Kreativitas Dan Aktivitas Industri Bordir Minangkabau Melalui Model Pembelajaran Desain Di Balai Diklat Indusri (BDI) Regional II Padang, Prosiding Konvensi Nasional Asosiasi Pendidikan Teknologi Dan Kejuruan (APTEKINDO) Ke 7 FPTK UniversitasPendidikanIndonesia, Bandung, 13 Sd.14 November 2014 